PRIMER NOTE

\title{
A set of primers for length and nucleotide-substitution polymorphism in chloroplastic DNA of Olea europaea L. (Oleaceae)
}

\author{
G. BESNARD,*+R. RUBIO DE CASAS $\ddagger$ and P. VARGAS \\ *UMR INRA/UHP 1136 IaM, Université de Nancy I, Faculté des sciences, BP 239, 54506 Vandœuvre Les Nancy, France, +UNIL, \\ Institut d'écologie, BSG, Bâtiment de Biologie, 1015 Lausanne, Switzerland, †Royal Botanic Garden, CSIC, Plaza Murillo 2, 28014, \\ Madrid, Spain
}

\begin{abstract}
Chloroplastic DNA (cpDNA) variation at five microsatellite motifs, two insertion-deletion sites, and eight nucleotide substitution sites was investigated in the Olea europaea complex. Primers were designed for flanking regions of these sites to amplify short cpDNA regions. They provided polymorphism when polymerase chain reaction (PCR) products from a representative sample of $128 \mathrm{O}$. europaea individuals were either resolved by size into polyacrylamide gels (length polymorphism) or digested with restriction enzymes (nucleotide-substitution polymorphism). These polymorphisms serve to distinguish most of the cytoplasmic haplotypes previously recognized. Potential application of these markers in O. europaea includes phylogeography, conservation and germplasm identification, even when using poorly preserved material from herbarium specimens or forensic and archaeological materials.
\end{abstract}

Keywords: chloroplastic DNA, microsatellite, Olea, olive, single nucleotide polymorphism

Received 21 July 2003; revision accepted 24 September 2003

The Olea europaea L. complex consists of the olive tree (ssp. europaea) and five closely related siblings (Green 2002): ssp. laperrinei (Batt. \& Trabut) Ciferri, ssp. cuspidata (Wall. ex G. Don) Ciferri, ssp. guanchica P. Vargas et al., ssp. maroccana (Greuter \& Burdet) P. Vargas et al., and ssp. cerasiformis (Webb \& Berth.) Kunkel \& Sundig. Phylogeographic reconstructions have been addressed by using chloroplastic DNA (cpDNA), but low variation was observed within this species (Vargas \& Kadereit 2001; Baldoni et al. 2002; Besnard et al. 2002). Five Mediterranean cpDNA haplotypes were distinguished by Besnard et al. (2002) using microsatellite motifs (ccmp5 and ccmp7; Weising \& Gardner 1999) and insertion-deletion (indel) variation in the $\operatorname{trn} \mathrm{Q}-\mathrm{t} r n \mathrm{R}$ fragment by polymerase chain reaction-restriction fragment length polymorphisms (PCR-RFLPs) (Dumolin-Lapègue et al. 1997). The PCR-RFLP technique usually needs the amplification of large DNA fragments (i.e. from 2000 to

Correspondence: Guillaume Besnard. UNIL, Institut d'écologie, BSG, Bâtiment de Biologie, 1015 Lausanne, Switzerland. E-mail: gbesnar@hotmail.com
$5000 \mathrm{bp}$ ), and consequently requires DNA templates of suitable quality. Lack of resolution in certain cases led us to pursue the finding of more variable molecular markers to distinguish populations in the Olea europaea complex. A second objective is to improve previous techniques, so they can be applied on herbarium specimens (Besnard \& Bervillé 2002).

Olea europaea sequences for three cpDNA regions (i.e. $m a t \mathrm{~K}, \operatorname{trn} \mathrm{T}-\mathrm{trn \textrm {L }}$ and $\operatorname{trn} \mathrm{Q}-\mathrm{trn} \mathrm{R}$ ) are now available in EMBL databanks (see Table 1 for Accession nos). Considering these cpDNA regions, we defined a set of primer pairs (Table 1) enabling PCR-amplification of polymorphic cpDNA fragments in the O. europaea complex. Length polymorphism was investigated at five single-nucleotide microsatellite motifs (four in $\operatorname{trn} \mathrm{Q}-\operatorname{trn} \mathrm{R}$ and one in $\operatorname{trn} \mathrm{T}-\operatorname{trn} \mathrm{L}$ ) and two indel sites of $8 \mathrm{bp}$ and $10 \mathrm{bp}$ in $\operatorname{trn} \mathrm{Q}-\operatorname{trn} \mathrm{R}$, whereas eight nucleotide substitutions were analysed using the PCRRFLP procedure (two in matK, four in trnQ-trn R and two in trnT-trnL; Table 1). Primers were designed for the flanking regions of each polymorphism (Table 1). Each PCR reaction mixture contained $10 \mathrm{ng}$ of DNA template, $1 \times$ reaction 
Table 1 Primer pairs for cpDNA amplifications of 128 individuals from the Olea europaea complex. Chloroplast DNA regions, GenBank Accession nos, fragment names and size variants, polymorphism types and annealing temperatures $(T)$ are also indicated

\begin{tabular}{|c|c|c|c|c|c|c|}
\hline $\begin{array}{l}\text { cpDNA } \\
\text { region }\end{array}$ & $\begin{array}{l}\text { GenBank } \\
\text { Accessions nos }\end{array}$ & Fragment name & Polymorphism type & $\begin{array}{l}\text { Fragment } \\
\text { size (bp) }\end{array}$ & $T\left({ }^{\circ} \mathrm{C}\right)$ & Primer sequence $\left(5^{\prime}-3^{\prime}\right)$ \\
\hline $\operatorname{trn} \mathrm{T}-\mathrm{L}$ & $\begin{array}{l}\text { AY040806 to } \\
\text { AY040816 }\end{array}$ & trnT-L-polyT & LP; Poly T & $79,80,81$ & 56 & $\begin{array}{l}\text { F: *AGGAAGAAATCAAAGAAGGG } \\
\text { R: ATACTGGAACCCTTGAATTC }\end{array}$ \\
\hline $\operatorname{trn} \mathrm{Q}-\mathrm{R}$ & $\begin{array}{l}\text { AJ577575 to } \\
\text { AJ577578 }\end{array}$ & $p s b \mathrm{~K}-t r n \mathrm{~S}-$ polyT/A & LP; Poly T - Poly A & $108,109,110,111$ & 53 & $\begin{array}{l}\text { F: *AAACCTCATTTCTTGGTGTC } \\
\text { R: GTAAGCATTACACAATCTCC }\end{array}$ \\
\hline $\operatorname{trn} \mathrm{Q}-\mathrm{R}$ & $\begin{array}{l}\text { AJ577575 to } \\
\text { AJ577578 }\end{array}$ & $\operatorname{trn} \mathrm{G}-$ polyT & LP; Poly T & $86,87,88$ & 52 & $\begin{array}{l}\text { F: *GGATTTAATCCTTTACCTCTC } \\
\text { R: CACTTTCTAAATGACTCATG }\end{array}$ \\
\hline $\operatorname{trn} \mathrm{Q}-\mathrm{R}$ & $\begin{array}{l}\text { AJ577575 to } \\
\text { AJ577578 }\end{array}$ & $\operatorname{trn} \mathrm{G}-\mathrm{R}$-polyT & LP; Poly T & 60,61 & 52 & $\begin{array}{l}\text { F: AATTTCTCACATACAATCCG } \\
\text { R: }{ }^{*} \text { CGTATTTTGACTTTTCTACC }\end{array}$ \\
\hline $\operatorname{trn} \mathrm{Q}-\mathrm{R}$ & $\begin{array}{l}\text { AJ577575 to } \\
\text { AJ577578 }\end{array}$ & trnS-G-indel-1 & LP; 10-bp indel + Poly T & $105,114,115,117$ & 55 & $\begin{array}{l}\text { F: *GATAAAGGAAGGGCTCGAAC } \\
\text { R: AGGCCATCAGAATAAGAAGG }\end{array}$ \\
\hline $\operatorname{trn} \mathrm{Q}-\mathrm{R}$ & $\begin{array}{l}\text { AJ577575 to } \\
\text { AJ577578 }\end{array}$ & trnS-G-indel-2 & LP; 8-bp indel & 52,60 & 53 & $\begin{array}{l}\text { F: CAAATCAGGAATTTCTTTTTAG } \\
\text { R: *TAGGCTCGTTCGAGCCCTTC }\end{array}$ \\
\hline $\operatorname{trn} \mathrm{T}-\mathrm{L}$ & $\begin{array}{l}\text { AY040806 to } \\
\text { AY040816 } \\
\text { AY040806 to } \\
\text { AY040816 }\end{array}$ & $\operatorname{trn} \mathrm{T}-\mathrm{L}-A c s \mathrm{I}$ & RS; AcsI & $\begin{array}{l}118 \rightarrow 118 \\
118 \rightarrow 95+23 \\
81 \rightarrow 81 \\
81 \rightarrow 37+44\end{array}$ & 53 & $\begin{array}{l}\text { F: GTGTCTATAGAATATAGAAAAGG } \\
\text { R: ATTAGAATTGTGATAAAGAAATC } \\
\text { F: }{ }^{*} \text { CCATCTATATTGAATTGCCG } \\
\text { R: TTTCTTCCTTATCGGAAACC }\end{array}$ \\
\hline matK & $\begin{array}{l}\text { AF359497 to } \\
\text { AF359504 }\end{array}$ & matK-RsaI & $\mathrm{RS} ;$ RsaI & $\begin{array}{l}109 \rightarrow 109 \\
109 \rightarrow 42+67\end{array}$ & 55 & $\begin{array}{l}\text { F: CAACGGAGAGTTCTGAGTC } \\
\text { R: *CCTATCCATTTATTCATTTGACCC }\end{array}$ \\
\hline matK & $\begin{array}{l}\text { AF359497 to } \\
\text { AF359504 }\end{array}$ & matK-TaqI & RS; TaqI & $\begin{array}{l}91 \rightarrow 91 \\
91 \rightarrow 43+48\end{array}$ & 55 & $\begin{array}{l}\text { F: *GAAAAAGCAACCAGCTTCTGTTC } \\
\text { R: GTCCTTGCCGTATCAGGCAC }\end{array}$ \\
\hline $\operatorname{trn} \mathrm{Q}-\mathrm{R}$ & $\begin{array}{l}\text { AJ577575 to } \\
\text { AJ577578 }\end{array}$ & $\operatorname{trnS-G-MseI}$ & RS; MseI & $\begin{array}{l}80 \rightarrow 32+48 \\
80 \rightarrow 32+5+43\end{array}$ & 53 & $\begin{array}{l}\text { F: *GCTATCAAAACTTCTTCAGC } \\
\text { R: ATAAGATTCTGAAAGGAGGG }\end{array}$ \\
\hline $\operatorname{trn} \mathrm{Q}-\mathrm{R}$ & $\begin{array}{l}\text { AJ577575 to } \\
\text { AJ577578 }\end{array}$ & $\operatorname{trnS}-\mathrm{G}-\mathrm{NdeI}$ & RS; NdeI & $\begin{array}{l}78 \rightarrow 78 \\
78 \rightarrow 55+23\end{array}$ & 55 & $\begin{array}{l}\text { F: *CTTTAGTCCACTCAGCCATC } \\
\text { R: AAAGAAAGACYCCTTACATCAT† }\end{array}$ \\
\hline $\operatorname{trn} \mathrm{Q}-\mathrm{R}$ & $\begin{array}{l}\text { AJ577575 to } \\
\text { AJ577578 }\end{array}$ & $\operatorname{trn} \mathrm{G}-P s t \mathrm{I}$ & RS; PstI & $\begin{array}{l}63 \rightarrow 63 \\
63 \rightarrow 44+19\end{array}$ & 52 & $\begin{array}{l}\text { F: *CAAGACTTCCAATTGAATAAG } \\
\text { R: GAAATCTACTTTCTATCTGCA† }\end{array}$ \\
\hline $\operatorname{trn} \mathrm{Q}-\mathrm{R}$ & $\begin{array}{l}\text { AJ577575 to } \\
\text { AJ577578 }\end{array}$ & $p s b \mathrm{~K}-\mathrm{trnS}-\mathrm{MseI}$ & RS; MseI & $\begin{array}{l}79 \rightarrow 64+15 \\
79 \rightarrow 37+27+15\end{array}$ & 55 & $\begin{array}{l}\text { F: CTATTCCACACGTTTAACTAAG } \\
\text { R: }{ }^{*} \text { TCTTTCCGGTTCCGTTGATG }\end{array}$ \\
\hline
\end{tabular}

*Primer labelled with the fluorochrome IRD800.

+Bold nucleotides indicate nucleotide changes comparatively to the reference Accessions ( $\mathrm{T} \rightarrow \mathrm{C}$ for $\operatorname{trnS}$-G-NdeI and $\mathrm{T} \rightarrow \mathrm{G}$ for $t r n \mathrm{G}-\mathrm{Pst \textrm {I } )}$ to create an absence-presence

polymorphism of a restriction site (NdeI or PstI, respectively).

LP, length polymorphism; RS, restriction site polymorphism (nucleotide substitution). 
buffer (Invitrogen), $2.5 \mathrm{~mm} \mathrm{MgCl}_{2}, 0.2 \mathrm{~mm}$ dNTPs, $0.2 \mu \mathrm{mol}$ of each primer (one of each primer pair was $5^{\prime}$-labelled with the IRD800 fluorochrome; MWG-Biotech), and 0.75 units of DNA polymerase (Invitrogen) in a total volume of $25 \mu \mathrm{L}$. Reaction mixtures were incubated in a thermocycler (I-cycler, Bio-Rad), first for $4 \mathrm{~min}$ at $94{ }^{\circ} \mathrm{C}$, and then for 36 cycles consisting of $1 \mathrm{~min}$ at $94{ }^{\circ} \mathrm{C}, 1 \mathrm{~min}$ at the optimized annealing temperature (Table 1) and $1 \mathrm{~min}$ at $72{ }^{\circ} \mathrm{C}$. The last cycle was followed by a $6 \mathrm{~min}$ extension at $72{ }^{\circ} \mathrm{C}$. Digestions of eight PCR fragments (Table 1) were performed using restriction enzymes TaqI, RsaI, AcsI, PstI, MseI (Invitrogen) or NdeI (BioLabs Inc.) according to the manufacturer's recommendations. Electrophoresis of DNA fragments was carried out on a denaturing $8 \%$ polyacrylamide gel using a 4200 LiCor automated sequencer (LiCor Inc.).

Each polymorphism was used to characterize 128 individuals chosen to represent the six subspecies of the O. europaea complex and the cytoplasmic diversity previously reported (Besnard et al. 2002). The same DNAs of 126 individuals were previously analysed for other chloroplast markers by Besnard et al. (2002): 31 individuals of ssp. cuspidata from South Africa to China (11 populations), five individuals of ssp. maroccana (Morocco, two populations), six individuals of ssp. guanchica (Canary Islands, three populations), two individuals of ssp. laperrinei (southern Algeria, two populations), 82 individuals of ssp. europaea from the Mediterranean Basin including 70 oleasters (17 populations) and 12 cultivars. In addition, DNAs from two herbarium samples of ssp. cerasiformis (Funchal, Madeira, J. Gonzalés 368; San Gonçalo, Madeira, Newberry 2) were extracted using DNeasy Plant Mini Kit (Qiagen) and analysed.

The 14 investigated fragments of the three cpDNA regions were easily PCR amplified using the above conditions. Thirty-four polymorphic variants were recognized (Table 1). The use of the molecular markers herein presented, together with those published in Besnard et al. (2002), allowed the identification of 22 cpDNA haplotypes. Length polymorphism variation in the $\operatorname{trn} \mathrm{Q}-\operatorname{trn} \mathrm{R}$ fragment obtained by Besnard et al. (2002) using PCR-RFLP was not fully congruent with the polymorphism described in the present study. DNA fragment sizes were incorrectly estimated by Besnard et al. (2002) because two or more mutations affecting nucleotide variation yielded similar PCR-RFLP fragments. This has been tested further by sequencing the $\operatorname{trn} \mathrm{Q}-\mathrm{R}$ region (unpublished data). In the trnS-G-indel-1 fragment, the 10-bp deletion was present in one variant size (105 bp; Table 1) and was found only in samples from the Mediterranean Basin and Sahara. Thus, in the trnS-G-indel-1 fragment, two characters should be individually considered (the 10-bp indel and single nucleotide variations in the poly T stretch). In the trnS-G spacer, an 8-bp indel (trnS-G-indel-2) and a restriction site (trnS-G-
MseI) were both detected in two western Mediterranean haplotypes (namely COM1 and COM2; Besnard et al. 2002). A restriction site ( $p s b \mathrm{~K}-t r n \mathrm{~S}-\mathrm{Mse} \mathrm{I})$ was specifically detected in the subspecies maroccana, cerasiformis and guanchica. Polymorphisms found in fragments matK-RsaI, matK-TaqI, trnG-PstI and trnG-polyT serve to identify ssp. cuspidata. Furthermore, Asian and African samples of this subspecies were segregated by PCR-RFLP size variants of the trnT-LTaqI fragment and by length variants in the trnG-R-polyT microsatellite motif. However, length variation in $p s b \mathrm{~K}$ trnS-polyT/A microsatellite motifs was incongruent with both previous data and taxa identification, suggesting probable occurrence of homoplasy at this site.

DNAs from herbarium samples were successfully amplified using all primers (Table 1), as previously reported for ccmp5 and ccmp7 primers (Besnard \& Bervillé 2002). It is possible to identify 20 of the 22 haplotypes so far designated by using the molecular markers herein described coupled with two cpDNA microsatellites (ccmp5 and ccmp7). Only two related haplotypes from Kenya (namely CA2 and CA3) can not be distinguished. Potential application of the above-mentioned primers and techniques in Olea includes phylogeography, conservation and germplasm identification, even when using poorly preserved material from herbarium specimens or forensic and archaeological materials.

\section{Acknowledgements}

We thank S. Jeandroz and J.M. Favre for their helpful comments on this manuscript. This work was supported by the project BIODIBERIA (A82).

\section{References}

Baldoni L, Guerrero C, Sossey-Alaoui K, Abbott AG, Angiolillo A, Lumaret R (2002) Phylogenetic relationships among Olea species based on nucleotide variation at a non-coding chloroplast DNA region. Plant Biology, 4, 346-351.

Besnard G, Bervillé A (2002) On chloroplast DNA variations in the olive (Olea europaea L.) complex: comparison of RFLP and PCR polymorphisms. Theoretical and Applied Genetics, 104, 1157-1163.

Besnard G, Khadari B, Baradat P, Bervillé A (2002) Olea europaea (Oleaceae) phylogeography based on chloroplast DNA polymorphism. Theoretical and Applied Genetics, 104, 1353-1361.

Dumolin-Lapègue S, Pemonge MH, Petit RJ (1997) An enlarged set of consensus primers for the study of organelle DNA in plants. Molecular Ecology, 6, 189-191.

Green PS (2002) A revision of Olea L. (Oleaceae). Kew Bulletin, 57, 91-140.

Vargas P, Kadereit JW (2001) Molecular fingerprinting evidence (ISSR, Inter-Simple Sequence Repeats) for a wild status of Olea europaea L. (Oleaceae) in the Eurosiberian North of the Iberian Peninsula. Flora, 196, 142-152.

Weising K, Gardner RC (1999) A set of conserved PCR primers for the analysis of simple sequence repeat polymorphisms in chloroplast genomes of dicotyledonous angiosperms. Genome, 42, 9-19. 